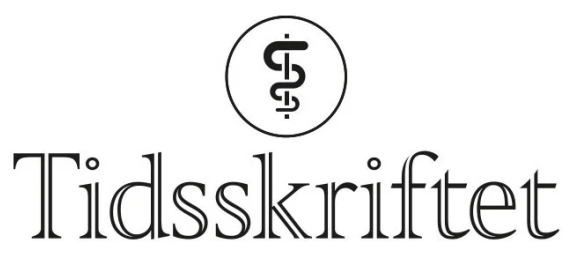

DEN NORSKE LEGEFORENING

\title{
Gliacellenes rolle ved epilepsi
}

RETTELSER

KJELL HEUSER

KAROLINA SZOKOL

ERIK TAUBøLL

I Tidsskriftet nr. 1/2014 s. 38 skal det i linje 3-4 i figurteksten stå: Glutamat frisatt ved synaptisk aktivitet blir tatt opp via glutamattransportører lokalisert i astrocyttmembranen. Vi beklager feilen. Den er rettet på nett.

Publisert: 11. februar 2014. Tidsskr Nor Legeforen. DOI: 10.4045/tidsskr.14.0050

(C) Tidsskrift for Den norske legeforening 2023. Lastet ned fra tidsskriftet.no 26 . april 2023. 